\title{
Sperm Protein Associated With the Nucleus on the X Chromosome C
}

National Cancer Institute

\section{Source}

National Cancer Institute. Sperm Protein Associated With the Nucleus on the X

Chromosome C. NCI Thesaurus. Code C92979.

Sperm protein associated with the nucleus on the $\mathrm{X}$ chromosome $\mathrm{C}(97 \mathrm{aa}, \sim 11 \mathrm{kDa})$ is encoded by the human SPANXC gene. This protein may be involved in spermatogenesis. 